\title{
Corrigendum: The effects of soluble corn fibre and isomaltooligosaccharides on blood glucose, insulin, digestion and fermentation in healthy young males and females
}

\begin{tabular}{|c|c|}
\hline Authors: & \\
\hline Ryan P. Lower & \\
\hline Jacob M. Wils & $o n^{2}$ \\
\hline Andrew Barni & nger $^{2}$ \\
\hline Matthew H. SI & narp ${ }^{2}$ \\
\hline Christopher Ir & $\operatorname{vin}^{2}$ \\
\hline Matthew Stef & \\
\hline William A. Wa & llace $^{2}$ \\
\hline Gabriel J. Wils & $o n^{3}$ \\
\hline Michael D. Ro & berts ${ }^{4}$ \\
\hline Ronald Wagne & $r^{1}$ (D) \\
\hline $\begin{array}{l}\text { Affiliations: } \\
{ }^{1} \text { Department } \\
\text { and Human Pe } \\
\text { Concordia Uni } \\
\text { United States }\end{array}$ & $\begin{array}{l}\text { ff Health } \\
\text { erformance, } \\
\text { versity Chicago, }\end{array}$ \\
\hline $\begin{array}{l}{ }^{2} \text { Applied Scien } \\
\text { Performance I } \\
\text { United States }\end{array}$ & $\begin{array}{l}\text { ce and } \\
\text { nstitute, }\end{array}$ \\
\hline $\begin{array}{l}{ }^{3} \text { Maximum Hu } \\
\text { Performance, }\end{array}$ & $\begin{array}{l}\text { man } \\
\text { United States }\end{array}$ \\
\hline $\begin{array}{l}{ }^{4} \text { Molecular an } \\
\text { Sciences Lab, } \\
\text { Kinesiology, A } \\
\text { University, Un }\end{array}$ & $\begin{array}{l}\text { d Applied } \\
\text { School of } \\
\text { uburn } \\
\text { ited States }\end{array}$ \\
\hline $\begin{array}{l}\text { Correspondin } \\
\text { Ryan Lowery, } \\
\text { rlowery@thea }\end{array}$ & $\begin{array}{l}\text { g author: } \\
\text { spi.com }\end{array}$ \\
\hline $\begin{array}{l}\text { Dates: } \\
\text { Published: } 31\end{array}$ & May 2018 \\
\hline $\begin{array}{l}\text { How to cite th } \\
\text { Lowery RP, Wi } \\
\text { Barninger A, e } \\
\text { Corrigendum: } \\
\text { of soluble corr } \\
\text { isomaltooligos } \\
\text { on blood gluce } \\
\text { digestion and } \\
\text { in healthy you } \\
\text { and females. J } \\
2018 ; 3(1), \text { a35 } \\
\text { org/10.4102/j }\end{array}$ & $\begin{array}{l}\text { is article: } \\
\text { Ison JM, } \\
\text { t al. } \\
\text { The effects } \\
\text { fibre and } \\
\text { accharides } \\
\text { se, insulin, } \\
\text { fermentation } \\
\text { ng males } \\
\text { insul. resist. } \\
\text { ir.ttps://doi. } \\
\text { ir.v3i1.35 }\end{array}$ \\
\hline Read online: & \\
\hline 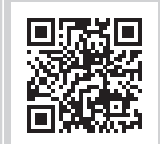 & $\begin{array}{l}\text { Scan this QR } \\
\text { code with your } \\
\text { smart phone or } \\
\text { mobile device } \\
\text { to read online. }\end{array}$ \\
\hline
\end{tabular}

\section{Authors:}

Andrew Barninge ${ }^{2}$

William A. Wallace 2

Affiliations:

Concordia University Chicago,

United States

${ }^{2}$ Applied Science and Performance Institute,

${ }^{3}$ Maximum Human

${ }^{4}$ Molecular and Applied

Kinesiology, Auburn

Corresponding author:

Ryan Lowery,

Dates:

How to cite this article: Lowery RP, Wilson JM,

Barninger A, et al.

Corrigendum: The effects

of soluble corn fibre and

isomaltooligosaccharides

digestion and fermentation

in healthy young males

and females. J. insul. resist.

2018;3(1), a35. https://doi.

org/10.4102/jir.v3i1.35

mobile device

to read online.
In the title of this article published earlier, the spelling of 'isomaltooligosaccharides' was unintentionally misprinted as 'isomaltooligosacharides'. The authors sincerely regret this error. The title should be corrected as follows: The effects of soluble corn fibre and isomaltooligosaccharides on blood glucose, insulin, digestion and fermentation in healthy young males and females. 